\title{
TRIBUNAIS DA SOCIEDADE: UM ESTUDO DAS ESTRUTURAS DECISÓRIAS DO DIREITO POR MEIO DOS SISTEMAS ORGANIZACIONAIS
}

\author{
SOCIAL COURTS: A STUDY OF LEGAL DECISION-MAKING STRUCTURES THROUGH \\ ORGANIZATIONAL SYSTEMS
}

Marco Antonio Loschiavo Leme de Barros*

\begin{abstract}
Resumo:
$\mathrm{O}$ artigo descreve, inspirado pela teoria dos sistemas sociais de Niklas Luhmann, a dinâmica dos tribunais na sociedade moderna. É destacado as implicações da constatação que tribunais podem ser observados tanto como centro do sistema jurídico quanto como uma organização periférica do sistema político e do econômico. Trata-se, em verdade, de observar os tribunais da sociedade. Por ocasião desta observação, uma nova tipologia é apresentada para lidar com a descrição dos tribunais nas sociedades modernas, tais como as ideias de cortes originais, deferenciais, consequencialistas e catalisadoras. Nesse sentido o texto avança em diferentes estudos das teorias das organizações para sustentar uma perspectiva funcionalista que permite lidar com o fato organizacional social. Trata-se de uma observação da atuação do tribunal por sua própria estrutura e função, não se limitando às operações de outros sistemas funcionais, como em soluções descritivas sobre as cortes como instâncias de controle ou de programação.

Palavras-chave: Tribunais. Teorias das organizações. Sociologia do Direito. Teoria dos Sistemas.
\end{abstract}

\begin{abstract}
:
The paper describes, inspired by Niklas Luhmann's theory of social systems, the dynamics of courts in modern society. It highlights the implications of the finding that courts can be observed both as the center of the legal system and as a peripheral organization of the political and economic system. It is an observation of social courts. On the occasion of this observation, a new typology is presented to deal with the description of courts in modern societies, such as the ideas of original, deferential, consequentialist, and catalyst courts. In this sense the paper advances in different studies derived from theories of organizations to support a functionalist perspective about the social organizational fact. It is an observation of the performance of the court by its own structure and function, not limited to operations of other functional systems, as in descriptive solutions about courts as forms of control or programming.
\end{abstract}

Keywords: Courts. Theories of organizations. Sociology of Law. Systems Theory.

\footnotetext{
* Doutor pelo Departamento de Filosofia e Teoria Geral do Direito da Universidade de São Paulo. Professor titular da Universidade Paulista e pesquisador da Universidade de São Paulo. E-mail: marco.barros@usp.br. 
1. Introdução

O tribunal ${ }^{1}$ é uma importante organização para o funcionamento das sociedades modernas. Isso foi observado historicamente a partir da sua diferenciação como um sistema parcial distinto de tomada de decisão, responsável pelo controle das expectativas normativas contrafáticas, por meio da aplicação de textos legais. ${ }^{2}$

No século XIX, com a positivação do direito, tribunais começam a assumir esse papel de destaque na sociedade já que o direito reconhecido passava a ser aquele mantido pela força de uma decisão. Toda e qualquer expectativa precisava ser filtrada por meio de processos decisórios antes de assumir determinada forma jurídica. Isto pode ser compreendido pelo fato que tudo o que é jurídico passa a ser determinado a partir de suas próprias operações.

Se isto, de um lado, conferiu maior autonomia e preponderância para a atuação dos tribunais no interior do sistema jurídico, de outro, confirmou uma declarada crise da dogmática produzida no final do século XIX: o progressivo distanciamento da sociedade. ${ }^{3}$ No século XX duas posições distintas surgiram como possíveis encaminhamentos para a crise da dogmática, ${ }^{4}$ ora como um aperfeiçoamento do pandectismo, uma visão tributária do resgate histórico do direito romano, ora como uma retomada com a realidade como retratado na ideia de direito vivo de Eugen Ehrilch (2009), um direito para além do texto legal, aquele praticado pela sociedade, nos diversos usos e costumes, que independe de qualquer ordem estatal ou de qualquer tipo de sanção.

Nessas perspectivas tribunais são criticados tanto como excessivamente formalistas ou como excessivamente psicologizados. Se tribunais são originariamente

1 Utiliza-se o termo "tribunal" para designar indistintamente toda e qualquer instância decisória dentro do sistema jurídico que opera com base em programas condicionados - processo de tomada de decisão a partir do implemento de condições. Não é feita nenhuma distinção hierárquica entre tribunais. Nesse sentido, um tribunal pode se referir à organização tradicional que desempenha a função jurisdicional, mas também pode implicar em outras organizações extrajudiciais como tribunais de arbitragem ou tribunais administrativos.

2 Este texto não reduz a experiência do tribunal apenas ao período moderno. Conforme registros históricos, na Grécia Antiga existiam uma série de formas de resolução de controvérsias por meio de órgão de jurisdição como é o caso do Areópago em Atenas, outros exemplos poderiam ser oferecidos. Fato sublinhado apenas é que este texto adota como recorte as operações dos tribunais a partir da consolidação dos Estados nacionais.

3 Diz Tércio Sampaio Ferraz Jr. (2001, p. 81) sobre o desenvolvimento da dogmática a partir do século XIX, “(...) paga-se um preço por isso: o risco de um distanciamento progressivo da realidade, pois a ciência dogmática, sendo abstração de abstração, vai preocupar-se de modo cada vez mais preponderante com a função de suas próprias classificações, com a natureza jurídica de seus próprios conceitos etc.".

4 A crise da dogmática pode ser compreendida como um efeito correlato ao absolutismo jurídico, caracterizado por Paolo Grossi (2005, p. 193) ao afirmar que "é um esquema interpretativo que, na minha visão, tendia a esclarecer também as induvidosas - mas quase sempre ignoradas - consequências negativas das concepções jurídicas burguesas. O grito da Marselhesa e os foguetórios disparados para as cartas dos direitos impediram muitas vezes de advertir quão limitador e inatural tinha sido o grande processo de panlegiferação e de codificação nos séculos XVIII e XIX”. 
órgãos da sociedade - e não necessariamente órgãos estatais -, poderiam também fundamentar suas decisões a partir de normas de decisão advindas de toda e qualquer prática social. Não resta dúvida de que, nas últimas décadas, os tribunais ainda enfrentam uma declarada crise relacionada com uma incerteza sobre sua atuação e com a dogmática produzida - "fuga do direito" -, sobretudo, em relação às novas exigências políticas e econômicas do século XXI. ${ }^{5}$

Afinal, do ponto de vista da sociologia do direito, tribunais seriam tão somente meios de solução de conflitos, com o propósito de reduzir o máximo possível de perturbação social - instâncias de decisões de controle - ou também são instrumentos de planejamento, fator de modificação da vida social - instâncias de decisões programáticas? Trata-se de um questionamento sobre a atual função e operação dos tribunais.

Para alguns é o caso de compreender a passagem da centralidade da cultura do código para a da decisão, o que significa uma alteração do destaque social dado à figura do legislador para a do juiz - o que implica em entender as alterações programatórias no interior do sistema jurídico nas últimas décadas e que fortaleceram o poder dos juízes na sociedade. Evidências são extraídas de diferentes experiências da passagem do Estado Liberal para o Estado do Bem-Estar Social e, posteriormente para o Estado Pós-Social, marcando a pluralidade de fontes produtoras e de tipos de normas jurídicas, que não se encaixam plenamente em modelos hierárquicos formais de ordenamentos jurídicos.

De outra perspectiva, a centralidade dos juízes e tribunais na atualidade decorre, em verdade, de certa insuficiência do modelo judicial na sociedade complexa. Ao contrário da visão anterior, essa observação recai nas insuficiências da atuação judicial, que não conseguem filtrar e depurar as pressões externas no processo decisório. Em outras palavras, o Judiciário não consegue se imunizar das pressões de ordem política. A própria independência e neutralidade do judicial são colocadas sob suspeita, quando juízes parecerem exercer uma nova função jurisdicional, por vezes confundida com a administrativa ou a legislativa. Nesse sentido, considerando problemas da administração, observaram-se também o surgimento de outras estruturas decisórias e concorrentes ao Judiciário.

Diante da complexidade apontada como estudar essas organizações? Este texto recorre aos trabalhos da sociologia das organizações para apresentar um modelo exploratório de estudo dos tribunais, sobretudo ao percorrer algumas compreensões

Nesse sentido, por exemplo, seria fundamental perceber e comparar as transformações operadas em ordenamentos jurídicos nacionais vis-à-vis globais, estes que se consolidam independente de ordenamentos nacionais e que podem ser explicados por processos de diferenciação “(...) por um lado, com pouco respaldo político e institucional no plano mundial no plano mundial, por outro, ele [direito global] está estreitamente acoplado a processos sociais e econômicos dos quais recebe os seus impulsos mais essenciais". (TEUBNER, 2003, p. 11). Afinal, quais seriam as distinções operacionais entre tribunais "nacionais" e tribunais "globais"? 
iniciadas por Max Weber e retomadas, via bases distintas, por Niklas Luhmann. Ao observarem as organizações formais nas sociedades industriais e pós-industriais, esses teóricos salientaram - a partir de seus pressupostos - o fato organizacional como fenômeno social relevante e que desvela um sentido próprio de cada organização. No caso dos tribunais da sociedade - que se atenta ao fato social organizacional -, o interesse é preservar a complexidade pressuposta nas suas operações - não reduzindo a observação para um dos vieses da instância de controle ou de programação, enfatizando a especificidade da comunicação social que circula em suas estruturas.

\section{Sociologia das organizações}

Desde a constatação de Weber (1976) em Os fundamentos da organização burocrática: uma construção do tipo ideal que as organizações permitiram o desenvolvimento da sociedade moderna, já que possuem propósitos específicos e regras próprias de operação, inaugurando um regime das autoridades via as burocracias, o tema da "sociedade e organização" cresceu na literatura. Primeiro, ao avançar na leitura weberiana das organizações burocráticas, compreendendo o papel de algumas de suas características tais como: hierarquia, com determinação de deveres; regras preestabelecidas; membros assalariados e com dedicação exclusiva; separação das tarefas e distinção entre os trabalhadores e o controle dos meio de produção. Essa corrente busca relacionar o desenvolvimento de determinadas sociedades com a racionalidade formal pressuposta nas operações burocráticas. A organização permite controlar as ações individuais segundo critérios gerais.

Todavia, uma segunda corrente avançou o modelo weberiano ao destacar o deficit democrático notado diante do avanço das organizações no século XX. Mesmo formalmente operando segundo o modelo da racionalidade formal, organizações burocráticas podem ser ineficientes. Tal literatura destaca que Weber desconsiderou em suas análises outras dimensões da organização, como a vida informal e os ajustes com outros sistemas, afora as próprias disfunções da burocracia. Nesse sentido, o estudo dos laços informais é tão importante quanto a previsão das regras formais das organizações, da mesma forma o ambiente físico das organizações que influencia demasiadamente as operações - basta pensar na importância do tema da vigilância.

Na década de 1960, Tom Burns e George Stalker (1966), na obra The Management of Innovation, afirmaram que as organizações burocráticas podem engessar e prejudicar a inovação tecnológica, sendo preferível diferenciar as organizações mecânicas das orgânicas. As primeiras são os sistemas burocráticos weberianos, organizados hierarquicamente, com separação de tarefas e distinção do controle dos meios de produção. Um traço predominante é o anonimato na medida em que a tarefa não é vinculada ao 
sujeito e não possui uma interação entre os membros. Nessa linda esses autores afirmam que essas organizações são adequadas às produções tradicionais e estáveis, não sujeitas às alterações do mercado.

Em contrapartida Burns e Stalker afirmam que as organizações orgânicas possuem uma estrutura mais frouxa, reputando como importante os fluxos de comunicação, sendo que todos os membros da organização participam em alguma medida das tomadas de decisões. Importante traço é a flexibilidade; o que permite o rápido ajuste às transformações do mercado. Tais distinções são importantes para compreender a posição de uma literatura que destaca a mudança organizacional da sociedade, bem como temas do final do século $\mathrm{XX}$ que se vincularam com as organizações como os ajustes frente a tomada de decisões de baixo para cima, a menor especialização, a estabilidade no emprego e a fusão da vida profissional e privada.

Fato é que organizações podem ser estudadas a partir de seus próprios elementos e atuações. Adotando uma perspectiva funcionalista, seria possível discutir a ideia de fatos sociais organizacionais à luz dos fatos sociais de Émile Durkheim. Lembrando, fatos sociais são maneiras de agir, de pensar, de sentir compartilhadas por uma pluralidade de indivíduos e que, de certo modo, impõem-se a nós, que nos constrangem a agir, pensar e sentir determinada maneira, as organizações também possuem determinados modos que se impõe e transcendem os seus membros. ${ }^{6}$

O paralelismo proposto é entre a teoria das organizações e a dos fatos sociais. Isto porque a teoria do fato social em Durkheim pressupõe o primado da sociedade sobre o indivíduo, da mesma forma - em alguma medida - as organizações (e.g., tribunais) também antecedem a operação dos seus membros (e.g., juízes). Em um primeiro sentido reconhece-se a prioridade histórica. As sociedades coletivistas existiram anteriormente às sociedades individualistas.

O outro sentido é o da prioridade lógica que fornece explicação dos fenômenos sociais. Entende-se a sociedade antes de entender o indivíduo que dela faz parte - é o todo social que deve explicar o indivíduo (e não ao contrário). Isto porque a sociedade é compreendida como uma síntese gerada pela associação dos indivíduos, a qual produz uma realidade que apresenta existência e concretudes próprias independente das motivações individuais. Nesse sentido, para compreender as transformações sociais, é fundamental também observar as atuações das organizações, basta pensar na relevância

Vale lembrar que fatos sociais são muitas vezes compreendidos como intangíveis, não podem ser observados diretamente, suas propriedades devem ser examinadas indiretamente, analisando seus efeitos ou considerando suas manifestações. Uma postura científica nessa visão exige uma perspectiva que esteja aberta às evidências dos sentidos e livre de ideias preconcebidas. 
dos bancos para a economia, dos estados para a política, das universidades para a ciência, dos hospitais para a saúde e dos tribunais para o direito.

Diante desse recorte, o texto avança na discussão por meio de uma articulação exploratória dos sistemas organizacionais, apresentado por Niklas Luhmann na sequência.

\section{Sistemas organizacionais}

Organizações não se equivalem a sistemas funcionais. No texto Organização e Decisão (2005), publicado pela primeira vez em 1978, Luhmann sustenta o surgimento das organizações num contexto mais geral e anterior a sociedade mundial, na medida em que constituem sistemas de decisões e que se relacionam a partir de uma rede organizacional, ${ }^{7}$ possibilitando estímulos recíprocos e até mesmo o aparecimento de novas organizações. ${ }^{8}$

O sociólogo alemão Rudolf Stichweh (2011, p. 29, tradução nossa) aponta com clareza este insight na teoria luhmanniana destacando o uso ortogonal das comunicações organizacionais, diz:

Quando olhamos para a sociedade mundial do ponto de vista de uma teoria da diferenciação funcional, temos que argumentar que a organização formal representa um princípio ortogonal à diferenciação funcional. Esta é uma visão que Luhmann percebeu no início, quando ele entendeu que a caracterização parsoniana de atribuir todas as organizações à política como um sistema analítico é insustentável, pois implicaria relações de input/output extremamente complexas entre a política e todos os outros sistemas que não são mais plausíveis na sociedade contemporânea.

Ademais, há pressuposta certa ortogonalidade da organização em relação aos sistemas de função da sociedade mundial, comunicações organizacionais podem

\footnotetext{
7 As irmandades religiosas podem ser citadas como uma das primeiras organizações da sociedade moderna, pois atendiam à função decisória na comunidade e também disciplinavam a autoridade política. De acordo com Luhmann: "os sistemas organizacionais surgem originariamente em conexão com a necessidade de decisões sobre a ação coletiva (assim se explica o surgimento de aparatos de autoridades similares ao Estado), mas também em conexão com a economia monetária ou em condições de pluralismo religioso". (LUHMANN, 2005, p, 59, tradução nossa).

8 Não à toa, a configuração da sociedade mundial também foi acompanhada de uma expansão organizacional ao longo dos últimos séculos; uma análise mais aprofundada permite indicar que organizações anteriores foram determinantes para os surgimentos das novas e, em muitos casos, acabaram mimetizando estruturas semelhantes. Um exemplo trivial pode reforçar este ponto, consigo encontrar os mesmos serviços e produtos em um estabelecimento da empresa de tecnologia eletrônica "Apple" em Pequim igual ao estabelecimento em Los Angeles ou em São Paulo. Para uma discussão sobre as organizações mundiais, cf. Koch (2011).
} 
circular em vários sistemas de função e podem fazer parte dos processos que se seguem em uma mesma organização. ${ }^{9}$ Stichweh, novamente, afirma que as organizações podem ser multissistêmicas e multirreferenciais. Aliás, para o autor, os sistemas de função podem funcionar como atrativos para as organizações, pois são capazes de induzir autossimplificações que fazem com que as organizações prefiram se vincular a um sistema de função como a lógica de sua evolução futura (STICHWEH, 2011, p. 29-33).

Em uma linha próxima, Rocha e Azevedo (2012) argumentam que as organizações à luz do modelo sistêmico surgiram como aquisições evolutivas orientadas para a absorção das incertezas sociais. "Quando uma organização surge, nasce uma rede de decisões recursivas, e tudo o que sucede, em geral, ocorre como comunicação de decisões, ou se orienta para isso". (ROCHA; AZEVEDO, 2012, p. 207). A sociologia sistêmica passa, então, a observar a relação entre organização e sociedade a partir de sua distinção: a sociedade depende das operações organizacionais, mas, simultaneamente, se diferencia enquanto um ambiente social das organizações.

O sociólogo estadunidense Charles Perrow (1991), inclusive, aprofunda o ponto sobre a origem e dependência da sociedade em relação às sociedades. Para o sociólogo as organizações absorveram a sociedade, "elas [organizações] aspiraram (vaccumed up) uma boa parte daquilo que sempre pensamos como sociedade, na verdade se transformaram em um substituto da sociedade". (PERROW, 1991, p. 726, tradução nossa). ${ }^{10}$

Isto se observa na história. No final do século XX, observou-se uma forte vinculação dos sistemas funcionais em relação às organizações, especialmente encaminhada por meio de uma lógica burocrática. Segundo Luhmann, isto decorreu da capacidade das organizações de gerar redundância, prevenindo surpresas e absorvendo a insegurança (LUHMANN, 2016, p. 62). Não à toa, em cada sistema social existe uma série de organizações que produzem redundância necessária para a manutenção dos sistemas. ${ }^{11}$

$9 \quad$ Inegável reconhecer que existe um vasto campo inaugurado pela teoria dos sistemas sobre a sociologia das organizações, talvez a principal ideia sobre este campo seja a observação das organizações a partir do encadeamento de processos que levam à decisão. Assim, primeiro, a organização ocorre em relação à sua própria história de tomada de decisão. Segundo, embora os processos de decisão possam se referir ao ambiente externo, as decisões são sempre produtos internos e tornam-se relevantes apenas se forem comunicadas e compreendidas como decisões (como decisões comunicadas, não como atos individuais). Para uma discussão geral, cf. Holzer, Kastner e Werron (2015) e Rocha e Azevedo (2012).

10 Para o sociólogo estadunidense uma boa parte da explicação deste diagnóstico se relaciona com três pontos: a dependência salarial dos trabalhadores em relação às grandes organizações, o que eliminou a possibilidade do sujeito não ter outra atividade econômica competitiva fora das organizações; a externalização dos custos sociais, que reforçou a manutenção do poder das organizações na sociedade e a burocracia (no sentido weberiano de hierarquia e impessoalidade), que aumentou o controle das atividades econômicas, cf. Perrow (1991).

11 Uma observação sistêmica considera a expansão das grandes organizações nas últimas décadas, capazes de se impor sobre aquelas que administram o medium - e.g., as relações entre grandes empresas ou 
Nesta leitura, a organização é dotada de uma seletividade interna capaz de marcar sua diferença com o ambiente (e.g., ambiente interno do sistema) e ao mesmo tempo assegurar sua unidade. Toda e qualquer decisão organizacional serve de ponto de partida para decisões futuras, pois qualquer decisão pertence à unidade organizacional e fixa-se em pontos temporários, que garantem a continuidade de novas decisões. Numa visão sistêmica, “[a]s decisões não podem ser entendidas como mônadas, nem como fenômenos únicos; estão mutuamente condicionadas no sentido de que, sem outras decisões, não haveria base para decidir”. (LUHMANN, 2005, p. 43, tradução nossa).

Diferentemente de sistemas funcionais, que possuem uma estrutura invariável e codificada - ainda que programável e não hierarquizada - e estruturam a reentrada do ambiente no sistema (ou ambiente interno), organizações são mais permeáveis ao ambiente interno dos sistemas e da sociedade. Isto porque a comunicação organizacional é assegurada por uma estrutura hierárquica própria e que produz uma complexidade interna autônoma.

A hierarquia vincula-se, aqui, como uma cadeia de comando que garante que decisões sejam formalmente tomadas (e não necessariamente que exista uma concentração de poder no topo) a partir de qualquer informação externa à organização. ${ }^{12}$ Desta forma, também, se consolidam como estruturas: as premissas decisionais e a cultura organizacional. ${ }^{13}$

Destaquem-se duas observações. Primeira, a hierarquia propicia a comunicação entre as organizações, além de assegurar sua seletividade interna. Por isso, organizações não necessitam vincular-se o tempo todo a um único sistema de função, uma vez que são, em verdade, sistemas autopoiéticos per se e produzem suas próprias fronteiras operacionais a partir de decisões. Para a tomada de decisão, as organizações mantêm uma relação com os códigos, que auxiliam na construção das premissas decisionais e da cultura, ainda que as decisões sejam processos dependentes somente das operações organizacionais.

corporações e bancos, no sistema econômico, ou com o Estado, no sistema político. Para Luhmann, "grandes organizações deste tipo podem referir-se às particularidades de sua tecnologia produtiva, de seus procedimentos operacionais padrão, do capital investido, da competição internacional e, recentemente, às ideias de 'identidade corporativa' e 'cultura organizacional', a fim de afirmar e fazer valer suas operações no sistema. A rigidez destas organizações assegura o êxito de suas operações no ambiente interno dos sistemas, sobretudo diante de outras organizações mais flexíveis ou do medium. Elas se impõem como pessoas mais severas diante de pessoas mais tolerantes em uma conversa amistosa, e a capacidade de se impor recai, aqui, sobre a privação de possibilidades". (LUHMANN, 1995, p. 64, tradução nossa).

12 A hierarquia deve ser compreendida como uma distinção interna das organizações que determina a sua operação. Todavia, entre diferentes organizações ou entre sistemas funcionais e organizações não existe hierarquia.

13 Do ponto de vista sistêmico, a cultura organizacional pode ser encaminhada como premissas de decisão indecidíveis, cf. Rocha e Avezedo (2012, p. 204-208). 
Segundo, decisões podem ou não atender as funções de sistemas, operando com base no código e nos programas funcionais específicos. Para Luhmann (1995, p. 665, tradução nossa), do ponto de vista das organizações, a diferenciação funcional da sociedade avalizou um novo tratamento organizacional, e "[s]omente agora existe um nicho de know-how para isso. Somente agora há muito para decidir. E é somente agora que o ambiente vale a pena ser considerado complexo, que não pode mais, de dentro, enfrentar fatos, sinais ou representações, apenas por meio de decisões".

Assim, é possível perceber que sistemas funcionais desenvolvem, em alguma medida, organizações, as quais asseguram a continuidade de comunicações no interior dos sistemas, embora não precisem estar a todo o momento vinculadas aos limites funcionais.

Reitere-se, as delimitações dos campos de tomada de decisão das organizações não estão necessariamente vinculadas às funções e aos códigos; antes, são fixadas pela organização, que constantemente reconsidera suas fronteiras, uma vez que inovações são asseguradas pela possibilidade de se estabelecer novas relações com as decisões. Neste sentido, seria possível refletir também sobre a distinção de estruturas formais e informas das organizações, que segundo Holzer, Kastner e Werron (2015) marca as relações entre sistemas de função e organizações na sociedade mundial. ${ }^{14}$

Organizações podem observar e refletir diferentes informações do ambiente, porém limitadas por sua estrutura hierárquica, que possibilita inclusões e exclusões, especialmente quando promove a distinção entre membros e não membros. ${ }^{15}$ Para Luhmann, comunicação organizacional é compreendida a partir de e somente entre seus membros (LUHMANN, 2005, p. 188) e, por isso, vale pontuar que as organizações se baseiam nas expectativas formalizadas entre os membros para definir os parâmetros básicos da comunicação organizacional.

No caso do direito, tribunais surgem como uma diferenciação interna do sistema jurídico. Todavia, estas organizações não estão vinculadas aos limites funcionais, mas à comunicação produzida por suas operações (i.e., decisões judiciais). O quanto a evolução do direito da sociedade mundial se relaciona com a possibilidade e os avanços dos tribunais para outros ambientes é ponto de interessante investigação, pois, como

14 Diz Holzer, Kastner e Werron (2015, p. 38, tradução nossa): “Em contraste com a informalidade regular que está 'contida' em sistemas sociais específicos, também existem formas institucionalizadas de informalidade 'ilimitada', que atravessa os limites dos sistemas sociais, como as organizações. O interesse é saber, então, por qual motivo as estruturas formais são mantidas e operadas, mesmo diante da informalidade institucionalizada, o que leva à distinção de públicos globais e locais que sustentam orientações formais e universalistas ou informais e particularistas".

15 Segundo Luhmann (2005, p. 188, tradução nossa), "a decisão de aderir como membro da organização é também uma decisão sobre aceitar as condições de adesão, e isso significa aceitar as premissas para decidir, incluindo as condições para sua legítima alteração ou ressignificação de tais premissas". 
afirmando anteriormente, a sociedade pode ser observada simultaneamente como vinculada e como ambiente das organizações.

Diante desta descrição, o texto sugere que o desdobramento da tomada de decisão consequencialista - argumento com base nas consequências - vem enfraquecendo esta visão de que tribunais limitam-se exclusivamente ao campo do direito, pois se relacionam e cada vez mais com organizações que não pertencem exclusivamente ao sistema jurídico - e.g., bancos, parlamentos, agências reguladoras, hospitais, universidades, entre tantas outras.

Discute-se, ainda, a pluralidade de métodos de argumentação baseados em tese em técnicas e critérios não jurídicos - e.g., econometria, estatística, teoria da escolha racional, teoria dos jogos, entre tantos outros. Os tribunais deparam-se, portanto, com um problema: como decidir casos substancialmente justificados por argumentos não jurídicos, ou que não foram satisfatoriamente filtrados pelos programas do direito? Estas situações indicam que a comunicação dos tribunais não é o mesmo que comunicação jurídica, sendo necessário para o sociólogo marcar uma distinção?

Basta observar o crescimento do debate sobre as técnicas e critérios para resolver os problemas da adjudicação das consequências, que são tratados e desenvolvidos pela via da argumentação jurídica, sobretudo por meio da atuação judicial. Tais argumentos geralmente questionam os efeitos sociais das decisões e são, portanto, selecionados e decididos pelo direito. Nesse sentido, a adjudicação deve ser observada como uma comunicação produzida pelos tribunais.

Mesmo com problemas de filtragem, i.e., sem programas adequados, decisões são tomadas pelos tribunais. A dificuldade reside, então, em garantir a qualidade da decisão, ${ }^{16}$ sobretudo porque decisões consequencialistas admitem um presente futuro - e não um futuro presente. Decisões consequencialistas, então, se aproximam do futuro de modo utópico já que reduzem complexidades imaginando e supondo certos eventos. ${ }^{17}$

16 Luhmann critica esta situação, pois "quanto mais considerações acerca do fim suporta uma decisão, tanto maior será a probabilidade de que esta resulte equivocada, porque o futuro segue desconhecido, mesmo para o juiz" (LUHMANN, 2016, p. 269) e, ainda, porque "[a] orientação pelas consequências das decisões, vista pelo padrão das ciências empíricas, nada mais é do que imaginação com força jurídica”. (LUHMANN, 2016, p. 510).

17 A utopia ao lado da tecnologia é uma forma de "desfuturização", que se relaciona com o presente futuro. Diz Luhmann sobre a utopia: "[a utopia] continua sendo um presente futuro e, pelo menos, um sinal infalível da presença de críticos. A utopia se afasta quando tentarmos abordá-la. Não desaparece, no entanto, enquanto durarem as condições estruturais da sociedade atual, mas pode se reinstalar com novos símbolos e significados, se os antigos forem desgastados por decepções e pelas novas experiências. As experiências recentes reforçam que esses futuros utópicos aceleram as mudanças da sociedade e podem mudar de forma tão rápida que nunca terão a chance de serem testados e obter confirmação em um presente". (LUHMANN, 1976, p. 143, tradução nossa). 
Do ponto de vista organizacional, esta operação utópica indica, na verdade, que tribunais não necessariamente operam somente com base no código e nos programas do direito. Diferentemente de outras organizações do direito, eles ultrapassam com mais facilidade a fronteira do sistema funcional e comunicam-se com a sociedade de outra forma.

Há, portanto, comunicação dos tribunais fora do direito, o que, de um lado, pode representar, dentro da visão sistêmica, outra forma de irritação do sistema jurídico, ou um desdobramento como "ambiente interno" do direito; de outro, permite compreender que tribunais não atuam exclusivamente no direito, participando também de outros sistemas sociais. Como explicar essas situações? Do ponto de vista sistêmico, é possível observar fatores estruturais que determinam como a comunicação dos tribunais pode circular fora do direito.

\subsection{Fatores estruturais dos tribunais}

Diferentes estruturas - limitadas pelas operações internas de cada sistema - contribuem para o ajuste da expansão da atuação dos tribunais nos diversos subsistemas sociais. Estes fatores estruturais podem ser organizados a partir da relação codificação/ programação, sendo que "o sistema só é invariante e sempre adaptado na forma estrutural de seu código. No nível de seus programas, no entanto, ele pode admitir a possibilidade de mudanças sem precisar temer uma perda de identidade”. (LUHMANN, 2016, p. 257).

No nível da programação, tribunais comunicam-se também fora do direito, ainda que adstritos às exigências de outros códigos. Vale lembrar que Luhmann, quando discute a programação, interpreta os valores dos códigos como possibilidades ou meios que aceitam formas diversas (LUHMANN, 2016, p. 257-258). Desta forma, para além dos acoplamentos estruturais, as vinculações entre outros sistemas podem ocorrer via organizações, em especial no nível da programação.

Assim, ilustrativamente, tribunais com frequência obstam a que o sistema político aplique a força pública ilegalmente, seja ao exercer o controle de legalidade dos atos administrativos, seja ao interpretar a regra de competência do julgamento de um impeachment. Ao mesmo tempo, esta atuação só é possível se o sistema político assegurar aos tribunais sua autodeterminação, proporcionando-lhes autonomia financeira e administrativa e permitindo-lhes que imponham pela força suas decisões. ${ }^{18}$

\footnotetext{
18 É por isso que Luhmann (2016) sustenta que a política deve a ampliação de seu leque de possibilidades ao direito e ao dinheiro; o direito, ao poder e ao dinheiro; e o sistema econômico, por fim, à política e ao direito (LUHMANN, 2016, p. 570-578).
} 
Em algumas situações, a expansão está relacionada à mobilização das consequências pelos tribunais no momento da tomada de decisão. No caso da política, questiona-se como as decisões dos tribunais são traduzidas como formas de pressão política, ou em que medida influenciam no processo legislativo. ${ }^{19} \mathrm{Sem}$ dúvida, o tribunal age como organização política quando suas decisões são comunicadas por meio do poder, colocando em evidência as consequências das decisões no sistema político, bem como quando contribuem para a delimitação judicial da política, resultando em produção de legislação ou de atos administrativos.

No que tange ao sistema econômico, verifica-se que decisões judiciais interferem nos processos econômicos, seja criando mecanismos de execução de créditos ou securitização dos riscos por meio de depósitos e garantias, seja adjudicando direitos sociais. Os tribunais acabam por administrar a escassez por meio de suas decisões, comunicando-se com a economia e colocando em debate os impactos de suas decisões em orçamentos públicos. ${ }^{20}$

Há uma situação contingente de reciprocidade entre esses sistemas em que a comunicação encontra-se vinculada por meio das organizações. Esta "correspondência" não simétrica marca a coevolução dos sistemas ${ }^{21}$ e acontece de maneira inconstante e em diferentes tempos - desarmonias temporais - por meio da redução da complexidade do ambiente a partir da própria comunicação produzida pelas organizações. Paradoxalmente, a comunicação organizacional é também condição de aumento de complexidade interna em outros sistemas circulantes.

Do ponto de vista da teoria dos sistemas, esta situação pode ser compreendida como um movimento de ajustes e equilíbrios da temporalidade da sociedade em seu conjunto, motivada por acelerações e desacelerações em função do tempo de cada sistema, inclusive das organizações. Vale lembrar que um dos grandes dilemas na leitura sistêmica refere-se ao futuro da sociedade mundial, que é "desfuturizado" via utopias e tecnologias. ${ }^{22}$

19 No direito constitucional brasileiro, geram efeitos no Poder Legislativo decisões sobre mandados de injunção ou ações de controle de constitucionalidade por omissão, tanto as vinculantes, dos tribunais superiores - e.g., súmula vinculante ou repercussão geral -, porque alcançam a Administração Pública em geral nos termos do art. 102, $\S 2^{\circ}$, da $\mathrm{CF} / 88$, como aquelas emanadas em mandados de segurança, ações de improbidade administrativa ou demandas relativas a direitos sociais e econômicos, por interferirem diretamente nas operações do Poder Executivo ou do Poder Legislativo e, mais importante, por sua capacidade latente de afetar disposições orçamentárias.

20 Cf. Bora (2010).

21 Esta coevolução não é finalística nem linear, mas uma diferenciação que implica acréscimos sucessivos de complexidade no sistema e, portanto, o desenho de novos limites operativos. Cabe enfatizar que a compreensão deste aumento de complexidade do sistema por meio de redução da complexidade do sistema via organização não é causal, pois depende da determinação estabelecida tão somente pelo sistema, observando-se, aqui, a distinção entre codificação/programação como estruturas internas de seleção. Sobre coevolução, cf. Luhmann (1995, p. 26-41).

22 Cf. Luhmann (1976). 
Todavia, este ponto é estruturalmente desdobrado com o acúmulo de conhecimento e a aceleração dos novos limites operativos em cada sistema: transformação de política em direito, delimitação jurídica da política, entre outros. O tratamento do futuro produz pressões ambientais, que, por sua vez, repercutem nos sistemas.

Em síntese, organizações se vinculam com o ambiente a partir de uma comunicação e função própria, oscilando o modo pelo qual se vincula com os códigos e programas dos sistemas sociais. Aliás, isto é evidenciado quando se observa a comunicação organizacional em particular.

Sob outra perspectiva que reforça o estudo sociológico das organizações, é possível concordar com a tese dos processos multicêntricos de gestão e da multiplicidade de injunções em uma mesma organização, que reforçam a possibilidade das diferentes vinculações que organizações podem estabelecer. Dutra e Campos (2013) discutem essa tese tendo em vista o problema da coordenação e do controle de desempenho organizacional - i.e., sob o referencial sistêmico, a gestão precisa privilegiar uma orientação funcional ao selecionar os objetivos organizacionais, o que produz tensões em termos operacionais.

Ninguém negaria que tribunais se preocupam mais em assegurar as expectativas normativas do que propriamente resolver os problemas de pagamentos, da mesma forma que prevalece nos hospitais a atenção em produzir diagnósticos e tratamentos do que lidar com a administração da escassez de medicamentos.

Todavia, não é possível negar também a variedade de gestão nestas organizações. Como já visto, tribunais se preocupam com as repercussões extrajurídicas de suas decisões da mesma forma que hospitais demandam o fornecimento de medicamentos para os seus pacientes. Nesse sentido, Dutra e Campos (2013, p. 24) sustentam que "a variedade funcional das organizações implica formas de gestão também distintas, de modo que podemos falar de uma gestão religiosa, uma gestão científica, uma gestão política, uma gestão da medicina etc.".

A variedade de formas de gestão organizacional revela, em verdade, os conflitos das gestões. É possível questionar, por assim dizer, sobre qual referência funcional prevalecerá as operações dos tribunais e quais são os desdobramentos disto em relação as demais operações. O mesmo poderia ser questionado em relação ao estado, bancos, escolas, universidades, hospitais etc.

A impossibilidade de estabelecer um único centro ou monopólio referencial funcional para cada organização em uma sociedade policontextual revela a complexidade do ponto.

Ao privilegiar uma referência funcional a organização não exclui as demais e sequer se isola, mas, gera irritações e tensões em outras operações e, inclusive, com outras organizações. Basta pensar na gestão política e econômica dos tribunais e o impacto 
disto nos órgãos de controle do estado ou mesmo em outras administrações do Judiciário como o Conselho Nacional de Justiça. ${ }^{23}$

Diante destas observações é possível afirmar que organizações também são formas e que existe um vasto campo de estudo sistêmico sobre as operações organizacionais e as suas dinâmicas na sociedade. ${ }^{24}$

\subsection{Forma de organizações}

Este texto desdobra a observação das organizações como uma forma marcada por dois lados, segue-se os apontamentos de Dirk Baecker (2006), que ao discutir a noção de empresa, apresenta o conceito de organização como forma.

O sociólogo economista alemão elenca cinco elementos para esta compreensão, a saber: é possível distinguir a organização pela sua história, pela sua cultura, pela referência sistêmica e pela comunicação organizacional. Vejamos em detalhes esses elementos.

A história é parte essencial de qualquer organização; esta conhece a si mesma, mas apenas parcialmente. Segundo Baecker, "a história da organização está incorporada em seus procedimentos, seus estatutos, suas regras escritas e não escritas, suas tecnologias, seus edifícios, sua missão, seus ideais e sua ideologia, suas pessoas, seu conhecimento, sua gestão, seus mercados e suas redes". (BAECKER, 2006, p. 112, tradução nossa). Trata-se de um conhecimento relativo, produzido pela organização, sendo fundamental para a compreensão das suas operações entender esse processo.

A ideia de cultura também é relevante, pois define a identidade da organização a partir de uma comparação. Baecker aborda a cultura organizacional também como uma forma, de modo que o conceito aponta para uma diferença. De um lado, cultura consiste na memória de crenças, valores, regras e suposições tomadas como válidas, uma vez que foram pensadas e firmaram-se como bem-sucedidas. A identidade, enquanto produto da cultura, escolhe como trata e é tratada por outras organizações ou outros parceiros sociais (BAECKER, 2006, p. 114). O outro lado - não marcado - engloba

23 De modo semelhante, Dutra e Campos (2013, p. 39) discutem a gestão do Sistema Único de Saúde e afirmam que esta organização é disputada por diferentes formas de gestão como a médica, científica, econômica e política. Explicam, "O problema decorre da tentativa de alterar politicamente o modo de operação do sistema funcional da medicina, já que esse sistema, centrado na identificação de doenças, opera justamente na contramão das políticas que buscam priorizar a prevenção em detrimento da atividade clínica de diagnosticar e oferecer tratamento. Não é um problema de falta de gestão; é um problema de conflito de gestão: o conflito entre a gestão política e a gestão medicinal no arranjo organizacional da saúde".

24 Inclusive, Perrow (1991), mesmo não sendo sistêmico, já sustentava que era preciso refletir cada vez mais sobre as organizações a partir de variáveis organizacionais. O interessante é que o referencial sistêmico justamente oferece essas variáveis a partir de conceitos como programas, acoplamentos estruturais e comunicação. Tal ponto é desdobrado na sequência. 
possibilidades não selecionadas; destarte, a cultura, como memória, é tanto a reprodução de determinados valores quanto a constante lembrança de opções alternativas que fazem esses valores aparecerem como seleções contingentes questionáveis. A abordagem "diferencial” da cultura das organizações possibilita uma análise crítica das operações a partir da memorização, que é continuamente ativa na ação social ou na comunicação. A cultura de uma organização marca, ao mesmo tempo, a ideia de sua preservação e de sua transformação.

Outro aspecto importante é saber qual referencial sistêmico considerar ao estudar uma organização, pois é este que esclarece o modo como uma organização produz e se reproduz diferenciando-se do seu ambiente. Mesmo que organizações não estejam limitadas por sistemas de função, é necessário situar, no momento da observação, o sistema ao qual a organização está vinculada.

Em outras palavras, no nível da análise, deve-se explicitar qual sistema específico está sendo observado. É possível adotar diferentes perspectivas de observação, admitindo-se, portanto, um cenário com múltiplos ambientes e, ainda, sistemas diversos compatíveis com uma organização que opere nesses ambientes.

Propõe-se, aqui, um modelo de tribunal correspondente a uma organização diferenciada da sociedade que, ainda que tenha surgido de uma diferenciação interna do sistema jurídico, não é exclusiva dele. O tribunal não é um equivalente do sistema jurídico em si, mas uma organização central do sistema capaz de operar perifericamente em outros sistemas. $^{25}$

Baecker (2006, p. 115) relembra, inclusive, que na perspectiva sistêmica assume-se uma chave ecológica dos sistemas, inexistindo um "supersistema" coordenando os demais. Assim, não é necessário desconsiderar a operação dos outros sistemas ao estudar uma organização, pois esta permanece funcionalmente vinculada aos demais sistemas.

Por fim, a análise de Baecker elucida que a distinção da empresa também ocorre em termos comunicacionais. Ele aduz que esta oposição necessita corresponder recursivamente à ideia de organização como uma diferença em relação aos demais sistemas

\footnotetext{
25 A referência ao sistema jurídico não responde a todas as questões relativas à reprodução do tribunal. Em outras palavras, o direito não determina diretamente o tribunal, da mesma forma que o direito não é o único a comportar a forma judicial. Na visão sistêmica, vale lembrar, tribunais assumem um papel central no direito pois desdobram o paradoxo da aplicação do código - dois valores opostos que são simultaneamente relevantes, mas não podem ser utilizados ao mesmo tempo no momento da adjudicação. Desta forma, toda e qualquer dúvida sobre a aplicação de programas condicionados advindos da periferia se desdobra neste paradoxo que é superado momentaneamente com a decisão judicial. É possível perceber, portanto, que tribunais, primeiro, não resolvem o paradoxo (apenas desdobram), e segundo; nem sempre suas operações são relevantes e necessárias para a operação do direito, salvo se existir dúvida ou conflito sobre programas. Além disto, muitas outras estruturas alternativas podem ser consideradas pelo direito para a tomada de decisão, que não se resume à atuação dos tribunais. Sobre a centralidade dos tribunais no sistema jurídico, cf. Luhmann (2016, p. 397-450).
} 
- funcionais e de interação. Assim, a empresa diferencia-se da sociedade - incluindo os vários subsistemas - e de todos os que dela não participam e que convivem com essa distinção. Somente um modelo comunicacional de empresa é capaz de atender à exigência desta distinção (BAECKER, 2006, p. 127).

Nesta visão, as organizações produzem seu próprio sentido, conforme suas respectivas dinâmicas - afinal, elas referem-se uns aos outros. ${ }^{26}$ Desta forma, por exemplo, a comunicação da empresa só faz sentido para os membros, ou para seus participantes, e é determinada pelas sucessivas decisões e estruturas internas, geralmente hierárquicas. Existe, portanto, uma distinção entre comunicação empresarial e comunicação não empresarial.

Não se trata, propriamente, de uma sobreposição imediata entre comunicações diversas de sistemas sociais, mas, em verdade, da produção de uma comunicação própria da empresa que contenha uma história (memória), uma cultura e também faça referência a diferentes sistemas funcionais simultaneamente. É o caso de reconhecer que há evolução por meio das decisões, que confere certa espessura a trajetória e distinção das organizações em relação aos sistemas de função.

Diante do exposto, trabalha-se, aqui, um modelo comunicacional de tribunal enquanto organização social. Este modelo, correspondente à ideia de empresa em Baecker, que permite compreender um valor de informação que, enquanto acomoda todos os tipos de pretensões, se encontra limitado pelas estruturas organizacionais, em especial por regras de competência e processuais.

Vale registrar que ao fazer uma comparação entre a forma organizacional de empresa e tribunal não se está assumindo a ideia que empresas se equivalem operativamente aos tribunais - como faz uma leitura crítica de inspiração foulcaultina, examinando a questão de poder nas organizações como Gibson Burrell (1988) -, ou ainda que exista uma orientação economicista ou um modelo privatista dominante nos tribunais. Ao contrário, discute-se a caracterização da forma de empresa para indicar a variedade de outros tipos organizacionais, cada uma com particularidade e características própria.

\footnotetext{
26 Resgate-se a ideia de comunicação na teoria dos sistemas sociais, a qual conserva um primeiro aspecto identificado como redundância, uma seleção de informações a partir da possibilidade de outras informações que devem ser consideradas simultaneamente, oscilando, por assim dizer, entre a informação selecionada e a não selecionada. Seu segundo aspecto importante diz respeito ao paradoxo: aceita-se como informação somente o que é novo, i.e., o que apresenta algum elemento-surpresa. Contudo, só é possível admitir uma informação transformando-a em mensagem já conhecida, encaixando a comunicação em padrões preestabelecidos. Há um complexo - uma forma inerentemente atada e em rede - no equilíbrio entre variedade e redundância sempre que a comunicação ocorre. Em síntese, comunicação lida com informação pelo par variedade/redundância.
} 
Tribunais, portanto, asseguram vinculações entre sistemas a partir da sua própria operação. Na sequência, é detalhada esta visão comunicacional dos tribunais a partir de uma contextualização de sua expansão na sociedade.

\section{Tribunais em contexto}

O final do século XX marcou o incremento da atuação dos tribunais na sociedade, coincidindo com uma onda de constitucionalização após a Segunda Guerra Mundial (GARDABAUM, 2013; HIRSCHL, 2007). Inúmeros motivos desencadearam esta expansão, pontua-se a constitucionalização de temas ligados a direitos fundamentais da terceira e quarta gerações e de mecanismos que permitem e facilitam o acesso direto da população aos tribunais foram fatores preponderantes. ${ }^{27}$

No caso brasileiro, a expansão do Poder Judiciário aconteceu especialmente nos anos 1990 e decorre, para além da conjuntura da redemocratização, do novo sistema de controle de constitucionalidade e da ampliação dos poderes do STF estabelecidos no texto constitucional. ${ }^{28}$

Verifica-se, neste ponto, uma dualidade nas operações dos sistemas sociais. De um lado, amplia-se o poder político dos juízes, que participam mais ativamente da comunicação política, acarretando uma nova organização das instituições representativas. Do outro, problematiza a capacidade de juízes e tribunais decidirem demandas complexas e de representarem os anseios da sociedade.

Discute-se, assim, a legitimidade das decisões judiciais em áreas sensíveis às políticas públicas, sobretudo em países onde juízes não são eleitos. ${ }^{29} \mathrm{~A}$ história revela que tribunais, por serem um poder contramajoritário, podem atuar como verdadeiras organizações políticas de oposição ao controlarem e restringirem certos atos de governo. ${ }^{30}$

Ainda que se discutam e critiquem os fundamentos do papel contramajoritário dos tribunais na sociedade - para alguns teóricos, ${ }^{31}$ não há alteração substancial do

27 Nesse sentido, sustenta Oliveira (2017, p. 132): “A expansão do Poder Judiciário no campo da política majoritária não é uma singularidade brasileira, e sim parte de um processo global, decorrente de ondas de constitucionalização que se deram em uma série de países, desde a segunda Guerra Mundial, passando por países Europeus, como Portugal e Espanha, países africanos e latino-americanos".

28 Entre os principais trabalhos que sustentam esse diagnóstico estão os de Arantes (1997), Vieira (2008), Vianna, Burgos e Salles (2007), Taylor (2007) e Arguelhes e Ribeiro (2016).

29 Subjacente à posição está a defesa da regra da maioria dos mandatários vis-à-vis as decisões judiciais. Discutem, portanto, o papel contramajoritário dos juízes e as limitações que este papel impõe na articulação com os outros poderes do Estado, inclusive alertando para o risco de um governo dos juízes, cf. Tushnet (2006) ou Waldron (2006).

30 Este é o apontamento de Taylor (2007, p. 227), para quem “a visão clássica dos tribunais como instâncias estritamente legais tem sido contestada pelas crescentes evidências de seu papel político e de seu impacto diário nas políticas públicas".

31 Para uma discussão no direito brasileiro, cf. Bustamante; Bustamante (2016). 
princípio majoritário quando se transferem decisões políticas a juízes, apenas uma razão instrumental que autoriza uma substituição deficitária de uma maioria legislativa por uma maioria judicial à luz de um regime democrático.

Isto posto, é possível estabelecer uma tipologia das observações sobre os tribunais na sociedade a partir de suas comunicações.

\subsection{Tipologias das observações sobre os tribunais na sociedade}

Esta dinâmica nas comunicações enfatiza não apenas o desempenho da função judicial dos tribunais no sistema jurídico, como também revela que alguns tribunais podem ser observados como centrais neste sistema, porém periféricos em outros sistemas. ${ }^{32}$

Do ponto de vista sistêmico, a observação dos limites de cada subsistema e o desdobramento destes paradoxos garantem que se evite um bloqueio estrutural na atuação dos tribunais na sociedade, sobretudo quando argumentos consequencialistas estão em juízo.

Segundo a observação do sistema jurídico, o Judiciário é poder do Estado, o qual atua tanto como controle dos demais poderes, quanto como responsável pela solução de conflitos da sociedade.

Todavia, o entendimento da tese dos tribunais enquanto organizações sociais permite ampliar e perceber outras operações suas, sobretudo a forma pela qual sua comunicação afeta o sistema político, ao influenciar a confiança das instituições estatais, ao formar opinião pública, ou ao exercer pressão política sob os demais poderes, proibindo, restringindo ou aplicando políticas públicas ou mesmo controlando a legalidade da atuação dos mandatários.

Do ponto de vista do sistema econômico, postula-se que tribunais influenciam o funcionamento dos mercados por meio de suas decisões. $\mathrm{O}$ argumento principal indica que, em uma economia de mercado, é fundamental que juízes assegurem certa previsibilidade das decisões para que negócios, investimentos e transações sejam

32 Apresenta-se, neste momento, uma nova semântica para lidar com a descrição dos tribunais, que inclui os conceitos de rede, circularidade operativa, eficácia e legitimidade como resultado da integração entre direito, política e economia. Indica-se, ademais, um duplo paradoxo: política e economia podem deixar de observar o direito por motivos políticos ou econômicos, ao mesmo tempo em que direito pode deixar de observar a política e a economia por motivos jurídicos. Tribunais lidam, simultaneamente, com este paradoxo em cada decisão consequencialista, pois prevalece uma dependência entre poder político/dinheiro e eficácia das decisões judiciais, que escapa ao direito, ao mesmo tempo em que se observa uma demanda por legitimidade ou por administração da escassez nas decisões judiciais, que foge à política e à economia. 
bem-sucedidos. Para tanto, juízes devem garantir a máxima proteção dos direitos individuais, em especial o direito de propriedade, e a adimplência dos contratos. ${ }^{33}$

Neste cenário, um tribunal moroso e com decisões pouco previsíveis interfere nas expectativas do mercado e gera impactos na economia, ainda que se constate a independência desta questão no que tange à existência de uma incerteza estrutural do processo decisório do direito, i.e., uma decisão é sempre arriscada, uma vez que seleciona entre opções excludentes. ${ }^{34}$ Esta incerteza estrutural é, muitas vezes, antecipada e precificada nos contratos e negócios ou mesmo pelo próprio juiz, quando fixa exigências de garantia do juízo.

Do ponto de vista comunicacional, portanto, é possível fazer referência a diferentes seleções de informações disponíveis na memória dos tribunais, que pode ser evocada de diversas maneiras.

Relembre-se que, numa perspectiva sistêmica, comunicação não é apenas transmissão de algum conteúdo, mas síntese de uma distinção entre informação, ato de comunicar e ato de entender. Neste sentido, é possível admitir a existência de um espectro da comunicação do tribunal que seleciona informações referentes a vários sistemas sociais.

Estas distintas seleções de informação e de comunicação podem ser representadas num espectro de cores, de modo que cada ponto deste espectro colorido enfatize uma dessas seleções.

Ilustrativamente, tribunais podem falar sobre economia (e então é possível analisar seu conteúdo informativo), mas também podem indagar por que e como falar sobre economia ( situação em que se explora o ato de comunicar), e assim sucessivamente. ${ }^{35}$ Abaixo, colacionou-se uma representação do espectro de comunicação dos tribunais a partir da variação das cores primárias (azul, vermelho e amarelo) e complementares. ${ }^{36}$

33 Cf. Arida et al. (2005).

34 Cf. Argueles, Falcão e Schuartz (2006).

35 Segundo Luhmann (2010, p. 298): "o ato de entender pode ocupar-se da informação, ou do comportamento expressivo do outro. Mas isso depende do fato de que se capte que tanto a informação, como o ato de comunicar, são seleções que devem manter-se distinguidas". Além disso, sobre a heterogeneidade e as organizações, veja Besio e Meyer (2015, p. 241, tradução nossa): "Nos concentramos em organizações como um tipo específico desta ordem fragmentada. Não só as organizações estão bem equipadas para lidar com a heterogeneidade, mas podem utilizar de forma ativa e estratégica a heterogeneidade existente e as possíveis contradições para alcançar seus objetivos. Em seus processos de tomada de decisão, as organizações transformam as diferenças institucionais e combinam diferentes lógicas. Ao fazê-lo, mesmo ou especialmente quando esses processos são altruístas, as organizações podem mediar heterogeneidade não só para si, mas também no nível social. Isso, finalmente, permite a continuidade da existência de lógicas heterogêneas".

36 No século XVIII, Jacob Christoph Le Blon testou diversos pigmentos e definiu as três cores primárias. Para os artistas interessados na teoria das cores, isto representou o início do desenvolvimento das técnicas de combinação que, posteriormente, ficaram conhecidas como cores complementares. No século XIX, o poeta Johann Wolfgang von Goethe elaborou um tratado sobre a teoria das cores, avançando nos estudos da física de Isaac Newton sobre o tema. 
Propõe-se, aqui, uma comparação metafórica com a teoria pictórica, segundo a qual cores primárias (não decompostas) formariam cores secundárias (composta por duas cores primárias) e terciárias (composta por uma cor primária e outra secundária); nesta figura, diferentes comunicações dos tribunais referentes aos sistemas funcionais da economia, da política e do direito seriam equivalentes às cores primárias, produzindo comunicações secundárias e terciárias a partir da sobreposição e combinação a partir da estrutura organizacional. ${ }^{37}$

O processo comunicacional é, portanto, variável e depende de escolhas, ao passo que o próprio tribunal elabora seu entendimento e incompreensão a partir dessas escolhas e que podem se vincular a diferentes códigos da sociedade. ${ }^{38} \mathrm{Da}$ mesma forma que essas comunicações geram redundância, o que permite uma expansão para novas seleções neste espectro de cores.

Igualmente, a comunicação dos tribunais é duplamente contingente: nada assegura que ao produzir uma comunicação sobre conteúdo econômico, político ou jurídico o tribunal fixará um sentido imanente e invariável; nem que o juiz (ego) compreenderá o sentido do legislador (alter) ao interpretar determinada lei. Há sempre necessidade de uma nova comunicação e esta se revela, inclusive, uma situação altamente arriscada.

Vale lembrar também que Luhmann (2016) analisa a comunicação organizacional a partir da ideia de superimposição de riscos sobre a decisão. Não se trata de um mero gerenciamento de riscos (risk management), mas de monitorar criticamente todas as decisões por meio da observação de segunda ordem. Inúmeras estratégias são mobilizadas para que organizações reduzam o risco, como a delegação de poderes e responsabilidades, imposição ou proibição de forma escrita e até mesmo fragmentação e reordenação de uma decisão. Assegurando a obrigação da tomada de decisão. Estas soluções organizacionais pretendem afastar o risco e equacionar o problema da dupla contingência; ainda assim, não eliminam o risco, mas asseguram a consistência. ${ }^{39}$

Percebe-se, portanto, que o espectro pode ser compatibilizado com maior ou menor consistência das decisões, i.e., obviamente se presume que a comunicação

37 É possível admitir a vinculação com outros sistemas de função. Neste sentido, talvez, seja possível fazer uma distinção entre a vinculação de sistemas mais frequentes (e.g., direito, política e economia) em relação aos tribunais vis-à-vis outros que só se vinculam em questões circunstanciais (e.g., religião, educação, ciência, esporte).

38 Luhmann (2010, p. 298) sustenta que a comunicação é a ocasião para que a autopoiese do sistema social realize-se, i.e., "o sistema cria seu próprio processo de observação e autocontrole".

39 Não à toa, para Luhmann (2016, p. 191, tradução nossa), trata-se de uma questão de consistência às decisões que é derivada das fórmulas de contingência. No direito, o sociólogo associa à ideia de justiça, mas quando discute à ideia em geral nas organizações, aborda o tema como um problema de probabilidade: "[n]a medida em que uma decisão sobre a assunção de risco deve ser tomada - e o risco pode ser considerado tanto na decisão favorável ou não -, a organização tenderá a concentrar as probabilidades na direção de um maior grau de probabilidade e/ou improbabilidade em direção a um maior grau de improbabilidade". 
do tribunal se sobrepõe à jurídica, todavia isto não elimina as possibilidades das outras comunicações - outras sobreposições e imiscuições.

É possível, ainda, desdobrar esta discussão por meio das estruturas, em especial ao se considerar que a autodeterminação dos tribunais depende da hierarquia e das sucessivas decisões passadas - i.e., da memória dos tribunais.

Para um encaminhamento desta parte, resgata-se aqui a classificação de Guarnieri e Pederzoli (2002), que também foi trabalhada por Celso Fernandes Campilongo (2002), preocupados em discutir a atuação judicial. Os autores relacionam as diferentes posições do espectro às estruturas dos tribunais, geralmente sintetizadas em duas variáveis: autonomia política e a criatividade judicial.

O papel judicial estaria, então, interligado à organização e aos traços do grupo de juízes, e este conceito examina a influência do comportamento dos juízes na tomada de decisões. O papel judicial é visto como um conjunto de valores e atitudes dos juízes que determinam a decisão.

No que tange aos critérios de avaliação dividem em: criatividade judicial, que implica que decisões podem ou não ser tomadas com base em leis preexistentes; e grau de autonomia judicial das instituições políticas (Poder Executivo e Poder Legislativo), que se presume a partir das garantias funcionais e administrativas dos juízes.

Elabora-se, portanto, uma tabela com os tipos ideais:

Tabela 1 - Tipologia dos papéis judiciais

\begin{tabular}{|c|c|c|c|}
\cline { 3 - 4 } \multicolumn{2}{c|}{} & \multicolumn{2}{c|}{ Autonomia política } \\
\cline { 3 - 4 } \multicolumn{2}{c|}{} & Baixa & Alta \\
\hline \multirow{2}{*}{$\begin{array}{c}\text { Criatividade } \\
\text { judicial }\end{array}$} & Baixa & Executor & Guardião \\
\cline { 2 - 4 } & Alta & Delegado & Político \\
\hline
\end{tabular}

Fonte: Guarnieri e Pederzoli (2002).

Estes quatro tipos ideais podem ser sintetizados da seguinte maneira:

Juiz-Executor. Trata-se da caracterização do juiz "boca da lei”. Esta figura admite baixa criatividade judicial, já que não há espaço para a argumentação e a interpretação jurídica na tomada de decisão, bem como estabelece o tribunal como órgão executor da vontade do legislador. Neste modelo, não se presume uma distinção precisa entre legislação e jurisprudência.

Juiz-Delegado. Trata-se da caracterização de um juiz subordinado a órgãos executivos, ainda que em casos de omissão legislativa reconheça-se, temporariamente, um espaço para o exercício da criatividade judicial (competência discricionária). Vale notar que nestes casos a superveniência de normas jurídicas sempre acaba vinculando e diminuindo a criatividade judicial. 
Juiz-Guardião. Trata-se da caracterização do juiz como última trincheira do ordenamento jurídico. Neste modelo, o juiz possui todas as prerrogativas para implementar direitos consagrados em textos legais, independentemente das considerações de impacto nos demais órgãos do Poder Executivo. Esta caracterização geralmente está relacionada ao desempenho da função contramajoritária dos tribunais, bem como à ideia de controle de constitucionalidade.

Juiz-Político. Trata-se da caracterização de um juiz realista, que não obnubila as escolhas políticas existentes no processo. Estas figuras exercem abertamente um poder político e não sofrem nenhum tipo de constrangimento diante das sólidas garantias funcionais e administrativas de que gozam.

Sustenta-se, neste texto, que os tipos ideias de Guarnieri e Pederzoli podem ser ampliados - por meio de um enfoque funcionalista, como é o caso da sociologia sistêmica - e transportados às considerações sobre o modelo comunicacional dos tribunais mencionado. Destarte, não são propriamente os comportamentos dos juízes que definem o campo de atuação, mas as interações que estão vinculadas a própria estrutura comunicacional que opera as informações e o ato de comunicar e de entender.

Relembre-se, ademais, que o tribunal sempre faz referência a determinado sistema funcional, ${ }^{40}$ ainda que não esteja limitado por estas fronteiras. ${ }^{41}$ Geralmente, por se tratar de casos que exigem a manutenção de uma expectativa normativa, observa-se com muita frequência a atuação dos tribunais no centro do direito.

Há situações, todavia, em que tribunais podem e acabam atuando na periferia de outros sistemas mesmo que, do ponto de vista do direito, possam ser ilegais. ${ }^{42} \mathrm{O}$ modelo comunicacional revela, neste ponto, que tribunais precisam enfrentar o problema da dupla contingência a partir da relação entre legislação e jurisprudência, portanto, toda decisão é criativamente arriscada e provisória no modelo todo, e não referente apenas ao direito.

Sugere-se, portanto, um modelo mais funcional para o acompanhamento da atuação dos tribunais, uma tipologia alternativa que retrate a maneira como o tribunal descreve-se enquanto organização da sociedade.

$\overline{40}$ É possível sugerir que esta referência é explicitada, na prática, a partir da norma jurídica desafiada e o problema apresentado em juízo marcam a alternância entre um comportamento e outro - e.g., é o pedido que define os contornos da lide.

41 Trata-se de observar um paradoxo, pois, os tribunais precisam desdobrar ao decidir um caso quais e como observam os limites dos sistemas em suas operações. Tal perspectiva se aproxima da discussão proposta por Dutra e Campos (2013), quando discutem a ideia de conflito de gestões das organizações.

42 Vale lembrar que do ponto de vista sistêmico, operações do lado ilícito também estão situados dentro do direito, logo esta comunicação é ainda uma operação jurídica. Diz De Giorgi (2017, p. 271): “O fechamento do sistema realiza-se pela ativação do código binário direito/não direito. O direito, portanto, é um componente de uma distinção. Isso significa que quem produz direito produz também não direito". 
Estes tipos representam, contudo, distorções, reduções e simplificações, possuindo pontos cegos, justamente por serem tipos ideais. Na prática, as diferentes operações sobrepõem-se em razão da complexidade da comunicação, o que se traduz no fato de que uma decisão no sistema jurídico pode estender-se a outras posições organizacionais em diferentes sistemas.

Sem admitir qualquer atribuição normativo-corretiva, esta tipologia apresenta uma posição heurística para a compreensão da multiplicidade de posições em relação à atuação dos tribunais na sociedade, inspirada em classificações de Young (2012), de Guarnieri e Pederzoli (2002), Campilongo (2002), e, sobretudo, nas reflexões luhmannianas.

Figura 1 - Tipologia dos tribunais.

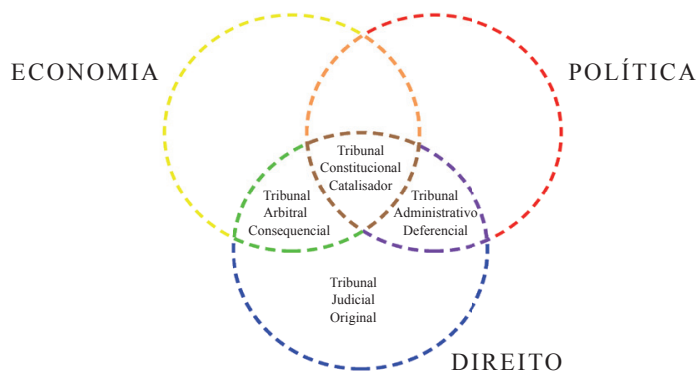

Fonte: Barros (2018).

Cumpre perceber, primeiramente, que tribunais são organizações que fazem referência ao direito, ainda que outros tipos também façam, simultaneamente, referências a outros sistemas funcionais. Neste sentido, todo tribunal origina-se do problema de tomada de decisão pelo direito.

Segundo, a distinção entre tribunais reporta-se mais à posição no direito do que propriamente aos comportamentos, por isso é possível assumir que algumas organizações estão no centro e outras, na periferia. Tribunais centrais - i.e., o tribunal judicial original - tomam a decisão final para desdobrar o paradoxo do direito (adjudicação do código); tribunais periféricos decidem provisoriamente sobre programas com referência às informações oriundas de outros sistemas, vinculadas, por vezes, aos arranjos contratuais e societários, ou delineamentos de políticas públicas. ${ }^{43}$

\footnotetext{
43 Na visão sistêmica admite-se, portanto, que diferenças entre esses tribunais marcam uma diferença em relação a seu isolamento cognitivo ou à sua permeabilidade a temas mais abertos e indeterminados.
} 
Terceiro, e como já mencionado anteriormente, tribunais não precisam respeitar limites funcionais. Do ponto de vista organizacional, não é um problema indicar que em algumas comunicações há evidente transposição de ruídos da economia e do direito para tribunais arbitrais, do direito e da política para tribunais administrativos, ou a dos três sistemas para tribunais constitucionais. Há uma verdadeira comunicação organizacional limitada apenas pela organização.

A representação das intersecções não indica uma corrupção de códigos, uma colonização de sistemas ou, ainda, uma não diferenciação, apenas enfatiza que há comunicação organizacional para além dos sistemas funcionais e que, também para os sistemas, organizações são uma forma de vinculação com os ambientes. Os círculos devem ser literalmente compreendidos como a circulação de uma comunicação específica, sempre aberta a seleções futuras.

Por fim, cada uma dessas comunicações seleciona de maneiras distintas a informação e o ato de comunicar. É dizer, tribunais arbitrais comunicam-se diferentemente de tribunais administrativos, tal como tribunais judiciais e constitucionais. Em relação à comunicação, não se presume uma hierarquia entre estes tribunais, ainda que em muitos ordenamentos e do ponto de vista jurídico, a fim de assegurar a segurança do direito, sustentem a convergência e a superposição dos tribunais.

Na sequência, serão detalhados cada um dos tipos ideais, ${ }^{44}$ a saber: (a) tribunal judicial original; (b) tribunal administrativo deferencial; (c) tribunal arbitral consequencial; e (d) tribunal constitucional catalisador.

\section{Tribunal judicial original}

Do ponto de vista das operações do direito, tribunais possuem a tarefa de supervisionar a consistência das decisões jurídicas. Eles observam outros programas, inclusive decisões que já tinham observado o direito anteriormente - procedendo, neste caso, a uma observação de segunda ordem no direito, "usada para examinar até que ponto a consistência da observação do direito permite que sejam integradas novas informações ou mudanças da periferia". (LUHMANN, 2016, p. 437).

Ele ocupa, portanto, uma posição originalista e peremptória no centro do sistema e precisa desdobrar o paradoxo sobre a adjudicação do código legal/ilegal.

\footnotetext{
44 Adota-se, aqui, a noção weberiana de tipo ideal; não se trata de uma reprodução exata de fenômenos sociais, mas de uma abstração que permite sua definição por meio da ênfase a um ou vários aspectos, valorizando sua interdependência, seus nexos causais e seus significados. Cada tipo ideal corresponde a uma experiência histórica distinta e múltipla, cabendo ao pesquisador desprezar os detalhes menos relevantes e destacar os mais importantes; o tipo ideal não é prescritivo nem possui um sentido ético, apenas descreve e possibilita a observação da sociedade pela ciência.
} 
Geralmente, neste espaço verifica-se uma interpretação canônica dos diplomas legais e também uma forte tradição de respeito aos precedentes, admitindo-se, nesses casos, uma presunção de extrema força de superação para aplicação de outros materiais e argumentos extrajurídicos (pareceres, opiniões, provas emprestadas, etc.) a despeito de qualquer avaliação do impacto da decisão na sociedade, ou de qualquer consideração externa a eles, de forma que o tribunal judicial original guarda semelhanças com a representação do juiz-guardião.

Sustenta-se que esta perspectiva justifica-se numa linha atenta ao funcionamento dos tribunais dentro do sistema jurídico e preocupa-se com questões sobre autorreferência, estabilidade das expectativas normativas e previsibilidade das decisões judiciais. Estes tribunais, especificamente, estão associados à função do direito e operam exclusivamente com a comunicação jurídica, respeitando seus códigos e programas condicionados.

\section{Tribunal administrativo deferencial}

O modelo deferencial de tribunal circunda uma concepção fraca de constitucionalismo e até mesmo uma corrente dialógica do vínculo entre organizações. Juízes devem ser analisados em relação aos demais poderes, pois decidem ora em favor do governo, ora da oposição. Esta perspectiva alcança o debate sobre a operação dos tribunais na periferia do sistema político ${ }^{45}$ e o equilíbrio entre os poderes, com especial reflexão sobre o fato de que determinados centros decisórios influenciam os resultados das políticas públicas, seja ao permitirem a discussão inicial de determinados temas, ao implementarem uma medida afirmativa ou mesmo ao retardarem uma decisão sobre questão sensível.

Tribunais administrativos começaram a surgir a partir das reformas na gestão pública defendendo instâncias decisórias com a presença de especialistas (não necessariamente juízes togados) ${ }^{46}$ Como visto, esta aposta de modernização sustentava-

45 Taylor pontua com clareza a posição da ciência política no que tange à atuação de juízes no sistema político: "A ciência política reconhece, há pelo menos meio século, que o Judiciário preenche um papel político como uma instituição para a tomada das decisões sobre questões controversas da política nacional. É sabido que muitas vezes os requerentes usam o Judiciário como mais uma oportunidade ou instância política - um 'venue' - e não como fonte de verdades constitucionais e legais. E se reconhece que os juízes frequentemente operam com base em critérios outros que os unicamente legais quando julgam processos importantes. Mesmo quando eles se mantêm constrangidos por critérios totalmente legais, pela própria natureza da revisão judicial, eles acabam tomando decisões que influenciam ou até criam políticas públicas". (TAYLOR, 2007, p. 248).

46 No caso brasileiro, no contexto da abertura internacional da economia surgiu a necessidade de modernização da estrutura administrativa, com especial ênfase em uma legislação adequada sobre o processo administrativo e em uma regulação setorizada. 
se na premissa de que, em alguns casos que envolviam conhecimento técnico, era melhor alocar a decisão a especialistas, em detrimento da via judicial, e setorizar a regulação de áreas. Assim, foram criadas agências reguladoras, conselhos e comitês decisórios.

Destaca-se que a atuação destes tribunais difere da judicial, assegurada pela delegação de competências e por textos legais flexíveis - i.e., conceitos jurídicos indeterminados e cláusulas gerais ou de princípios jurídicos. Em determinadas situações, tipos abertos ou legalmente indeterminados dependem explicitamente da complementação de um conhecimento técnico para ser capaz de fornecer soluções ao caso concreto, do que se presume um ruído proveniente do sistema político. Juízes administrativos dispõem de criatividade judicial, não vinculando tão solidamente o processo de tomada de decisão a determinada regra substantiva.

Todavia, não gozam das mesmas garantias dos tribunais judiciais, sobretudo porque podem ser submetidos a revisão judicial. Na verdade, estes tribunais acabam sendo constrangidos por autoridades estatais e reportam-se aos diferentes programas finalísticos da política, sujeitos a "correção de rota" a todo instante, além de estarem submetidos a constantes pressões governamentais.

Ainda vale lembrar que o caráter político desses tribunais está ligado por fatores como: trajetória das autoridades; método de seleção; repercussão da opinião pública; judicialização de determinadas demandas não programadas e abrangência das decisões.

\section{(c) Tribunal arbitral consequencial}

A terceira posição caracteriza os tribunais como consequencialistas, pois levam em consideração argumentos não jurídicos, em especial aqueles relacionados aos possíveis efeitos extrajurídicos da decisão. ${ }^{47}$ Uma corte consequencialista pode, portanto, flexibilizar interpretações canônicas e preferir avaliar e discutir prognósticos que enfatizem questões econômicas e problemas de uma justiça substantiva. Exemplos destes tribunais são as câmaras de arbitragem e meios alternativos de solução baseados na atuação de um árbitro e em soluções céleres.

Nos tribunais consequencialistas, a operação de juízes ocorre na periferia do sistema econômico, sobretudo quando tratam de problemas sobre a escassez e debatem contratos, ou, ainda, quando influenciam questões orçamentárias. Segue-se, aqui, um modelo que atende às exigências da comunicação econômica, como mais poder para soluções negociadas, celeridade nas decisões e ampla abertura de informações e revisão

47 É importante fazer a distinção entre tribunais consequencialistas e meios de operação do argumento consequencialista pelo direito, que pressupõe um filtro e uma observação sobre o funcionamento do direito. 
de posições. Em contrapartida, o direito homologa e reconhece a validade destas decisões, dotando-as de força executiva.

O caso dos planos econômicos no Brasil reforça esse ponto. O Judiciário há mais de três décadas demorou para decidir os casos da judicialização dos planos econômicos (Cruzado, Bresser, Verão, Collor I e II) e que se desenhou por meio de um acordo extrajudicial. Não à toa, o STF encontrou dificuldades em decidir a demanda - o que em alguma medida justificou a busca por uma alternativa extrajudicial e via o provisionamento de recursos. Isto pode ser compreendido a partir da fragilidade institucional da Corte em selecionar e avaliar as consequências econômicas de suas decisões diante de outras organizações mais periféricas e capacitadas para resolver problemas como este dos planos - como os tribunais de arbitragem.

Aliás, é importante destacar o problema do deficit informacional na tomada de decisão - seja em razão da fraca capacidade institucional de coleta e ponderação de indícios e provas, seja pela complexidade do problema desafiado - que dificulta a avaliação das consequências pelos juízes como no modelo de tribunal judicial original.

Luhmann (2005) aponta que esta dificuldade de avaliação renova-se frequentemente, pois o cálculo nunca é neutro em relação à realidade, de modo que a avaliação é revisada retrospectivamente, mesmo que a teoria da probabilidade pareça ajustada a essa prática, e, portanto, não apresenta estabilidade na dimensão temporal situação temida por praticamente todas as organizações (LUHMANN, 2005, p. 193-197).

Neste sentido, uma vez que os tribunais de arbitragem, em tese, operam de forma mais ajustada em relação aos problemas da avaliação, justificam-se o "boom" destas organizações e o efeito otimista gerado por sua consolidação em diferentes jurisdições a partir do século XXI. ${ }^{48}$

Novamente, este "boom" deve ser observado em conexão com a sociedade de experts. Tais descrições apostam na ideia problematizada neste texto de controle pelas consequências, cada vez mais presente nas operações dos tribunais de arbitragem.

48 Sublinhe-se importante conclusão de Chasin (2015, p. 174) sobre a implementação nos tribunais de arbitragem no Brasil, que aponta para a valorização constante da arbitragem, se comparada ao sistema de justiça oficial, nos últimos anos. O entusiasmo e a posição de destaque são assimilados, em grande medida, por meio dos discursos dos profissionais (árbitros, advogados especializados, estudantes e professores da área) em razão da qualidade, rapidez, previsibilidade, segurança, sigilo e especialização proporcionados pelo processo arbitral em detrimento do processo judicial. Ainda, a pesquisa indica que o próprio sistema de arbitragem no Brasil está ameaçado por "câmaras baixas". Segundo a autora, "na perspectiva da 'comunidade arbitral' aqui examinada, [existe] uma ameaça (embora nem sempre formulada desse modo) à credibilidade do instituto que defendem, o que acarretaria desvalorização e perda de prestígio. Tal como é comum a grupos de elite relativamente estabelecidos das mais diversas áreas e períodos, sua existência social apresenta-se como um fim em si, um valor a ser preservado. Para isso, é conveniente que a arbitragem se mantenha restrita ao pequeno circuito das altas câmaras ou que, na hipótese de ser ampliada para outros setores, a distinção seja demarcada". 
A quarta posição revela a figura de um tribunal catalisador, capaz de atuar nas margens dos sistemas e sem atentar-se aos limites funcionais operacionais para desencadear determinadas mudanças. Como apontado por Katherine Young, esta é uma metáfora útil para representar a multiplicidade de atuações dos tribunais, pressupondo-se uma gama de ações em outros sistemas (YOUNG, 2012, p. 172-174).

O tribunal catalisador admite certo grau de autoconhecimento pragmático da corte a fim de equilibrar os sistemas sociais; destarte, a corte possui uma sabedoria capaz de atuar no momento oportuno para exercer medidas mais ou menos intervencionistas.

Uma corte catalítica reflete, assim, a excessiva sobrecarga nas organizações - e vale a ressalva de que tribunais não são responsáveis pela separação dos sistemas funcionais, podendo, portanto, trabalhar com programas finalísticos ainda que necessitem alcançar uma decisão final.

Desta forma, para o direito, tribunais catalisadores evitam bloqueios sistêmicos, pois resolvem os conflitos intersistêmicos, os quais geralmente repercutem sobre a atuação de cortes constitucionais.

Estes tribunais vinculam centros da política e da economia, gerando ruído para o direito, quando, e.g., assimilam os riscos da escassez ou das decisões coletivamente vinculantes, determinam a necessidade de se fixar limites às despesas públicas, asseguram a autonomia do Banco Central, ou mesmo quando possibilitam o acesso de outras organizações à justiça, como movimentos sociais, organizações não governamentais, partidos políticos e governo, com o intuito de tutelar interesses interna corporis. ${ }^{49}$

O tribunal catalisador atua, em verdade, de maneira calculista e estratégica - aproximando-se da figura do juiz-político. Estes juízes, tais como os consequencialistas, sabem que a adesão à lei nem sempre é o fator determinante da tomada de decisão e Luhmann também sustenta este ponto ao questionar a existência de uma "ciência da legislação" cujas leis sejam "a base da racionalidade de todas as decisões jurídicas". (LUHMANN, 2016, p. 438).

Todavia, diferentemente do tribunal consequencial, este modelo barganha, blefa e cria empecilhos com interesses não evidentes ao mesmo tempo que possui amplas garantias de proteção. Além disto, na história, ficou fortemente marcado em sociedades welfaristas, que politizaram excessivamente o direito, sobrecarregando-o com expectativas

\footnotetext{
49 Deve-se lembrar de que frequentemente partidos políticos recorrem estrategicamente a tribunais constitucionais a fim de alterar decisões majoritárias nas quais foram derrotados (TAYLOR, 2008). Percebase que, assim, exercem a oposição por meio da judicialização.
} 
produzidas pela constitucionalização de políticas públicas e expandido os poderes dos tribunais.

Obviamente, essas instituições variam de acordo com a sociedade e o contexto. Juízes atuam como originalistas, deferenciais, consequencialistas ou catalisadores por diversos motivos, dentre os quais a flexibilidade que o texto constitucional e precedentes judiciais conferem-lhes para que interpretem e decidam um caso particular; sua visão política e filosófica; a capacidade do sistema político e econômico de filtrar e lidar com decisões judiciais indesejadas; o grau de apoio político e econômico que tribunais recebem de outras organizações públicas ou privadas; a cultura de independência judicial; o rule of law e até mesmo a criatividade judicial.

Para além desses tipos, a classificação admite combinações entre uma posição consequencial e uma deferencial como situação de experimentalismo, entre uma posição consequencial e uma original como situação gerencial e, por fim, entre uma posição deferencial e uma original como situação dialógica. Além disto, não surpreende que tribunais administrativos mimetizem estruturas dos tribunais judiciais, ou que tribunais arbitrais influenciem a abertura de outros tribunais; trata-se de situações intermediárias e dinâmicas que reforçam o caráter heurístico desta tipologia.

Não há uma análise predominante ou mais adequada. O foco está em traçar e indicar observações, destacando-se o aspecto funcional dos tribunais na sociedade. Vale apontar, portanto, que não se defende, aqui, determinada posição do tribunal nem se remonta a debates teóricos estruturados em argumentos polarizados e, por vezes, marcados por forte carga ideológica.

Lembre-se, ainda, que este texto apresenta uma observação de segunda ordem sobre os tribunais na sociedade, externa às organizações em destaque.

\section{Considerações finais}

Ante o exposto, este texto ofereceu uma tipologia que permite refletir sobre os tribunais da sociedade. Tal tipologia não pretende fazer um mapeamento exaustivo e sequer apresentar uma palavra final sobre as operações dos tribunais na sociedade. Tratase, antes, de discutir encaminhamentos sobre o fato organizacional a partir de diferentes recortes da história do Poder Judiciário em determinado país, bem como pensar sobre formas alternativas de estudar os tribunais enfatizando suas relação funcional com a sociedade.

No caso da sociedade brasileira muitas críticas ao desempenho das atividades jurisdicionais trouxeram novos elementos sobre a instalação e o desenvolvimento dos tribunais no país desde os primórdios do período colonial brasileiro (SADEK, 2004, 
p. 83), e vários estudiosos classificam-nos de maneiras diversas, como originalistas ou mesmo catalisadores.

Durante toda a década de 1980 e principalmente a partir da Constituição Federal de 1988 - após duas décadas de ditadura -, o temor de que sobreviessem novos períodos de exceção provocou uma valorização do sistema jurídico, com a juridificação de temas inéditos e o empoderamento das organizações jurídicas, consideradas mecanismos de contenção do arbítrio e de garantia de espaços de liberdade e de funções redistributivas - possivelmente uma aposta em modelos mais gerenciais, segundo a tipologia apresentado pelo texto.

Como resultado, verificou-se nos anos seguintes uma explosão de litigiosidade para a qual o Poder Judiciário brasileiro não estava preparado, e dois aspectos fizeram-se notar: (i) a atuação do Judiciário ainda é vista como problemática pela quase totalidade da população; ${ }^{50}$ e (ii) cresceu a intolerância com relação à ineficiência do Poder Judiciário, elemento-chave na explicação das dificuldades econômicas enfrentadas pelo país. $^{51}$

Para além dessas questões, na mesma época um novo desenho institucional, com outros participantes, é inaugurado: o Ministério Público assume novas atribuições, ampliando seu âmbito de atuação e seu prestígio (ARANTES, 1997) e são estabelecidas novas entidades no sistema de justiça, como a Defensoria Pública e os Juizados Especiais. Não por acaso, o Poder Judiciário, desde o processo de redemocratização, ganhou muito espaço na sociedade brasileira - caracterizada sobretudo por seu alto grau de judicialização, segundo os dados já apontados do ICJ-Brasil (CUNHA, 2017).

É possível admitir que a expansão dos tribunais ocorreu em razão de suas decisões deferenciais ou consequencialistas, seja por um maior empoderamento dos juízes conferido pelo texto constitucional, seja pelo paulatino controle e exposição da mídia. ${ }^{52}$

Do ponto de vista sistêmico, é possível apontar que os sistemas político e econômico podem transbordar seus riscos para o direito, sobretudo quando governos e

Cf. Cunha (2017).

Cf. Sadek (2004, p. 84).

52 Veja os apontamentos da pesquisa de Oliveira (2017, p. 142), diz: "O conjunto de dados discutidos aqui indicam não haver evidências robustas de que em sua atuação o STF estaria usurpando competências dos demais poderes, ou extrapolando suas funções ao decidir. O que observamos foram evidências de uma construção midiática que exacerba a personalização da instituição em seus ministros e enfatiza excessivamente em sua cobertura a judicialização anticorrupção. Uma vez que a grande maioria da população brasileira não tem qualquer contato com o STF, a não ser pela cobertura da grande imprensa ou pela TV Justiça, os meios de comunicação são centrais para informar a população sobre as atividades, os problemas e as virtudes do Supremo, e mesmo para traduzir a linguagem técnico-jurídica ao grande público". 
outras organizações abstêm-se de lidar com certas demandas, cenário em que tribunais surgem como um caminho possível.

Não à toa, verifica-se um importante protagonismo político e econômico do STF nos últimos anos em temas como a união estável homoafetiva ou no reconhecimento de acesso a determinados medicamentos, afora as conjunturas políticas envolvendo decisões diretas sobre a manutenção de determinados poderes de agentes políticos. Todavia, é relevante conhecer e compreender o impacto destas decisões, mais precisamente entender como ocorre esta expansão do tribunal pelo próprio tribunal - e não apenas se limitado às operações de outros sistemas funcionais, como em soluções descritivas sobre as cortes como instâncias de controle ou de programação.

Para tanto, o convite é analisar os diferentes tribunais, a partir de fatos sociais organizacionais, o que permite compreender a atuação do tribunal da sociedade sem a redução da complexidade da observação envolvida.

São Paulo, abril de 2019.

\section{Referências}

ARANTES, Rogério Bastos. Judiciário \& política no Brasil. São Paulo: Editora Sumaré, 1997.

ARGUELHES, Diego Werneck; FALCÃO, Joaquim; SCHUARTZ, Luis Fernando. Jurisdição, incerteza e Estado de Direito. Revista de Direito Administrativo, Rio de Janeiro, v. 243, p. 79-112, jan. 2006.

ARGUELHES, Diego Werneck; RIBEIRO, Leandro Molhano. Criatura e/ou criador: transformações do Supremo Tribunal Federal sob a Constituição de 1988. Revista Direito GV, São Paulo, v. 12, n. 2, p. 405-440, maio/ago. 2016.

ARIDA, Pérsio et al. Credit, interest, and jurisdictional uncertainty: conjectures on the case of Brazil. In: GIAVAZZI, Francesco; GOLDFAJN, Ilan; HERRERA AGUILERA, Santiago. Inflation targeting, debt, and the Brazilian experience, 1999 to 2003. Cambridge, MA: MIT Press, 2005.

BAECKER, Dirk. The form of the firm. Organization, London, UK, v. 13, n. 1, p. 109-142, 2006.

BARROS, Marco Antonio Loschiavo Leme de. Tribunais, complexidade e decisão: o argumento consequencialista no direito brasileiro. 382 f. 2018. Tese (Doutorado em Direito) - Faculdade de Direito, Universidade de São Paulo, São Paulo, 2018.

BESIO, Cristina; MEYER, Uli. Heterogeneity in world society: how organizations handle contradicting logics. In: HOLZER, Boris; KASTNER, Fatima; WERRON, Tobias. From globalization to world society: neo-institutional and systems-theoretical perspectives. New York: Routledge, 2015. p. 237-257. 
BORA, Alfons. Technoscientific normativity and the "iron cage" of law. Science, Technology, \& Human Values, v. 35, n. 1, p. 3-28, Jan. 2010.

BURNS, Tom; STALKER, G. M. The management of innovation. London: Tavistock, 1966.

BURRELL, Gibson. Modernism, post modernism and organization analysis 2: the contribution of Michel Foucault. Organization Studies, London, v. 9, n. 2, p. 221-235, April 1988.

BUSTAMANTE, Thomas da Rosa de; BUSTAMANTE, Evanilda Nascimento de Godoi. Jurisdição constitucional na era Cunha: entre o passivismo procedimental e o ativismo substancialista do STF. Revista Direito e Práxis, Rio de Janeiro, v. 7, n. 1, p. 346-388, jan./mar. 2016.

CAMPILONGO, Celso Fernandes. Política, sistema jurídico e decisão judicial. São Paulo: Max Limonad, 2002.

CHASIN, Ana Carolina da Matta. A assimilação da arbitragem no Brasil: disputas em torno da constituição de uma justiça extraestatal. 198 f. 2015. Tese (Doutorado em Sociologia) - Faculdade de Filosofia, Letras e Ciências Humanas, Universidade de São Paulo, São Paulo, 2015.

CUNHA, Luciana Gross (coord.). Índice de confiança na justiça brasileira - ICJBrasil. São Paulo: Fundação Getúlio Vargas, 2017.

DE GIORGI, Raffaele. Ciência do direito e legitimação: crítica da epistemologia jurídica alemã de Kelsen a Luhmann. Tradução de Pedro Jimenez Cantisano. Curitiba: Juruá, 2017.

DUTRA, Roberto Torres. Diferenciação funcional e a sociologia da modernidade brasileira. Política \& Sociedade: Revista de Sociologia Política, Santa Catarina, v. 15, n. 34, p. 77-109, set./dez. 2016.

DUTRA, Roberto Torres; CAMPOS, Mauro Macedo. Por uma sociologia sistêmica da gestão de políticas públicas. Conexão Política, Teresina, v. 2, n. 2, p. 13-49, ago./dez. 2013. Disponível em: http://www.ojs.ufpi.br/index.php/conexaopolitica/article/view/2967/1720.

EHRLICH, Eugen. Fundamental principles of the sociology of law. New Brunswick: Transaction Publishers, 2009.

FERRAZ JR., Tércio Sampaio. Introdução ao estudo do direito: técnica, decisão, dominação. 3. ed. São Paulo: Atlas, 2001.

GARDBAUM, Stephen. The new Commonwealth model of constitutionalism: theory and practice. Cambridge: Cambridge University Press, 2013.

GROSSI, Paolo. Absolutismo jurídico (ou: da riqueza e da liberdade do historiador do direito). Revista Direito GV, São Paulo, v. 1, n. 2, p. 191-200, jun./dez. 2005.

GUARNIERI, Carlo; PEDERZOLI, Patrizia. The power of judges: a comparative study of courts and democracy. Oxford: Oxford University Press, 2002.

HIRSCHL, Ran. Towards juristocracy: the origins and consequences of the new constitutionalism. Cambridge, MA: Harvard University Press, 2007. 
HOLZER, Boris; KASTNER, Fatima; WERRON, Tobias. From globalization to world society: neo-institutional and systems-theoretical perspectives. New York: Routledge, 2015.

LUHMANN, Niklas. Introdução à teoria dos sistemas. 2. ed. Petrópolis: Vozes, 2010.

LUHMANN, Niklas. O direito da sociedade. Tradução Saulo Krieger. São Paulo: Martins Fontes, 2016.

LUHMANN, Niklas. Organización y decisión. In: LUHMANN, Niklas. Organización y decisión: autopoiesis, acción y entendimiento comunicativo. Introducción y traducción de Darío Rodríguez Mansilla. Barcelona: Anthropos, 2005.

LUHMANN, Niklas. Social systems. Translated by John Bednarz Jr. with Dirk Baecker. Stanford, CA: Stanford University Press, 1995.

LUHMANN, Niklas. The future cannot begin: temporal structures in modern society. Social Research, Baltimore, v. 43, n. 1, p. 130-152, Spring 1976.

OLIVEIRA, Fabiana Luci de. O Supremo Tribunal Federal e a política no Brasil contemporâneo. Cadernos Adenauer, São Paulo, v. 18, n. 1, p. 125-148, 2017.

PERROW, Charles. A society of organizations. Theory \& Society, Basel, v. 20, n. 6, p. 725-762, Dec. 1991.

ROCHA, Leonel Severo; AZEVEDO, Guilherme de. Notas para uma teoria da organização da decisão jurídica autopoiética. Revista de Estudos Constitucionais, Hermenêutica e Teoria do Direito, São Leopoldo, v. 4, n. 2, p. 193-213, jul./dez. 2012.

SADEK, Maria Tereza. Judiciário: mudanças e reformas. Revista de Estudos Avançados, São Paulo, v. 18, n. 51, p. 79-101, maio/ago. 2004.

STICHWEH, Rudolf. Towards a general theory of function system crises. In: TEUBNER, Gunther; FEBBRAJO, Alberto; KJAER, Poul F. The financial crisis in constitutional perspective: the dark side of functional differentiation. Oxford: Hart Publishing, 2011. p. 43-60.

TAYLOR, Matthew M. Judging policy: courts and policy reform in democratic Brazil. Stanford: Stanford University Press, 2008.

TAYLOR, Matthew M. O judiciário e as políticas públicas no Brasil. Dados - Revista de Ciências Sociais, Rio de Janeiro, v. 50, n. 2, p. 229-257, 2007. Disponível em: http://www.scielo.br/pdf/ dados/v50n2/a01v50n2.pdf.

TEUBNER, Gunther. Bukowina global sobre a emergência de um pluralismo jurídico transnacional. Impulso: Revista de Ciências Sociais e Humanas, Piracicaba, n. 33, v. 14, p. 9-31, 2003. 
TUSHNET, Mark V. Weak-form judicial review and "core" civil liberties. Harvard Civil Rights - Civil Liberties Law Review, Cambridge, MA, v. 41, n. 1, p. 1-22, Winter 2006. Disponível em: http://web.archive.org/web/20120218231236/http://www.law.harvard.edu/students/orgs/crcl/ vol41_1/tushnet.pdf.

VIANNA, Luiz Wernek; BURGOS, Marcelo Baumann; SALLES, Paula Martins. Dezessete anos de judicialização da política. Tempo Social, São Paulo, v. 19, n. 2, p. 39-85, 2007.

VIEIRA, Oscar Vilhena. Supremocracia. Revista Direito GV, São Paulo, v. 4, n. 2, p. 441-463, jul./ dez. 2008.

WALDRON, Jeremy. The core of the case against judicial review. The Yale Law Journal, New Haven, v. 115, n. 6, p. 1.346-1.406, 2006.

WEBER, Max. Os fundamentos da organização burocrática: uma construção do tipo ideal. In: CAMPOS, Edmundo (org.). Sociologia da burocracia. 3. ed. Rio de Janeiro: Zahar, 1976. p. 15-28.

YOUNG, Katharine G. Constituting economic and social rights. Oxford: Oxford University Press, 2012. 